\title{
Kompetensi Metodologis Dosen Fakultas Sastra Universitas Al Azhar Indonesia dalam Pengajaran Kemahiran Berbahasa Asing
}

\author{
Faisal Hendra \\ Program Studi Sastra Arab, Fakultas Sastra, \\ Universitas Al Azhar Indonesia, Jl.Sisingamangaraja, Jakarta 12110 \\ E-mail: faisal_2104@uai.ac.id
}

\begin{abstract}
Abstrak - Ada lima unsur yang sangat mempengaruhi keberhasilan sebuah pengajaran dalam pembelajaran bahasa asing, kelima unsur ini adalah: Tujuan pengajaran, bahan ajar, metode pengajaran, media pengajaran/alat peraga dan teknik evaluasi. Untuk menunjang kualitas penguasaan bahasa asing yang dipelajari oleh peserta didik, diperlukan strategi dan metode yang tepat dan sesuai dalam proses pembelajaran. Kondisi peserta didik di pendidikan tinggi, kecakapan dan kemahiran dosen, dan lingkungan sekitar ikut menentukan strategi dan metode yang dipilih. Pemilihan metode yang tepat dalam pengajaran bahasa asing sangat menentukan tercapainya tujuan pembelajaran yang diharapkan. Disinilah peran penting pengajar dalam memilih metode yang tepat yang akan digunakan dalam pembelajaran yang diadakan. Sejauh tingkat ketercapaian satu materi yang diajarkan dalam proses pembelajaran? Jawabannya adalah sejauh mana juga pengajar memilih dan menggunakan metode yang tepat dalam pengajaran dimaksud.
\end{abstract}

Abstract - There are five factors which significantly influence the successful of the teaching and learning foreign languages. These are: the aims of teaching, the kind of material used, the method of teaching, the means or media of teaching and the evaluation techniques applied. The methodology and strategies of learning will support the best quality of proficiency of the learners. Other influencial factors to the choice of the strategies and the methods are: the condition of the learners, their proficiency, the quality of the lecturers and the environment. Indeed, the right method of teaching foreign language will determine the the final goal of learning. Therefore, the role of lecturer is crucial. How far the level of material difficulties can be achieved through the answer of how far the lecturer determines the right methodology to his teaching.

Keywords - competency, methodology, foreign language, language proficiency

\section{PENDAHULUAN}

1.1 Kompetensi Metodologis Pengajaran Bahasa Asing

Dengajaran bahasa asing sudah berlangsung Pejak lama di negara kita Indonesia, akan tetapi sampai saat ini masih dirasakan adanya "kegagalan" dalam pengajarannya untuk semua jenjang pendidikan. Hal ini dapat dilihat dari kemampuan rata-rata lulusan dari jenjang yang ada terkait penguasaan mereka terhadap empat kemahiran berbahasa yang diharapkan, mendengar, berbicara, membaca, dan menulis.

Idealnya, keempat kemahiran berbahasa itu harus dikuasai oleh seorang mahasiswa yang belajar bahasa asing secara berbarengan. Namun dengan segala keterbatasan yang ada, dari keempat kemahiran berbahasa itu, seorang siswa/mahasiswa yang belajar bahasa tampaknya lebih difokuskan dan diarahkan untuk bisa menguasai kemahiran membaca. Ini terlihat dalam pemfokusan unsur tata bahasa dan membaca dalam pengajaran dan pembelajaran. Walaupun pada hakekatnya, pemfokusan pengajaran bahasa asing kepada kemahiran tata bahasa dan membaca saja merupakan "penyimpangan" dari proses pembelajaran bahasa secara umum. Sebagaimana 
pembelajaran bahasa ibu, tahapan pembelajaran bahasa asing itu dimulai dengan pengenalan kosakata melalui kegiatan mendengar dan berbicara. Baru setelah itu menyusun kosakata menjadi frasa, klausa, dan kalimat, melalui kegiatan membaca dan menulis.

Untuk melihat sejauh mana penerapan konsep metodologi dalam pembelajaran bahasa asing oleh para dosen pengampu mata kuliah kemahiran berbahasa di Fakultas Sastra Universitas Al Azhar Indonesia penelitian ini diajukan, berharap, hasil dan data yang didapatkan nanti bisa digunakan untuk perbaikan mutu pembelajaran bahasa asing di Fakultas Sastra UAI pada khususnya dan ditingkat Universitas Al Azhar Indonesia pada umumnya.

\subsection{Tema Penelitian}

Guna untuk memfokuskan hasil penelitian yang diadakan, maka penelitian lebih spesifik membahas tentang: Kompetensi Metodologis Dosen Fakultas Sastra Universitas Al Azhar Indonesia Dalam Pengajaran Kemahiran Berbahasa Asing

\subsection{Tujuan dan Manfaat Penelitian}

Penelitian ini bertujuan untuk mendapatkan data yang akurat melihat sejauh mana penguasaan dosen pengampu mata kuliah kemahiran berbahasa dalam konteks penguasaan metodelogi pengajaran bahasa asing di Fakultas Sastra UAI.

\subsection{Batasan Masalah dan Pertanyaan Penelitian}

Penelitian ini membatasi masalah pada:

1. Bagaimanakah latar belakang penguasaan dosen kemahiran berbahasa di Fakultas Sastra UAI dalam penguasaan metodologi pengajaran?

2. Bagaimanakah metode dan cara yang dilakukan oleh dosen kemahiran berbahasa di Fakultas Sastra UAI terkait pengajaran bahasa asing yang ideal?

3. Bagaimana cara yang dilakukan oleh dosen kemahiran berbahasa di Fakultas Sastra UAI terkait teknik evaluasi ketercapaian bahan ajar?

\subsection{Tujuan dan Manfaat Penelitian}

Mengetahui secara jelas penguasaan dosen pengampu mata kuliah kemahiran berbahasa dalam konteks penguasaan metodelogi pengajaran bahasa asing di Fakultas Sastra UAI.
Mendapatkan data yang akurat sejauh mana penguasaan dosen kemahiran berbahasa asing di Fakultas Sastra UAI guna dilakukan terobosan baru untuk meningkatkan kemampuan belajar mahasiswa.

\section{KERANGKA TEORI}

Bahasa merupakan salah satu sarana vital yang sangat diperlukan manusia dalam hidup ini. Di era digital seperti sekarang ini, bahasa tidak lagi hanya sebagai sarana berkomunikasi dan berinteraksi. Lebih jauh dari itu, bahasa sudah menjadi agen budaya, peradaban, ilmu pengetahuan, dan teknologi. Nilai penting bahasa juga tampak pada saat kita menengok negara berkembang atau bahkan negara terbelakang sekali pun. Mereka mengetahui apa yang terjadi dan sedang berlangsung di negara maju melalui bahasa. Hal yang sama juga terjadi sebaliknya.

Untuk menunjang kualitas penguasaan bahasa oleh peserta didik, diperlukan strategi dan metode yang tepat dan sesuai dalam proses pembelajaran. Marilah kita berasumsi bahwa proses pembelajaran tidak hanya berkaitan dengan proses belajar siswa, baik di dalam kelas ataupun di luar kelas. Kondisi peserta didik dalam hal ini mahasiswa ditingkat pendidikan tinggi, kecakapan dan kemahiran dosen, dan lingkungan sekitar ikut menentukan strategi dan metode yang dipilih. Itu berkaitan erat nantinya dengan tujuan dan hasil pendidikan dan pengajaran bahasa Arab yang kita harapkan.

Prof. Mahmud Yunus (1942, dalam Arsyad, 2003:66) menyatakan bahwa 'metode jauh lebih penting daripada materi'. Karena itu, dalam bagian ini akan dibahas proses pembelajaran berikut metode yang diterapkan dalam proses itu. Berbagai metode sengaja dimuat agar menjadi bahan perbandingan sekaligus alternatif untuk menghadapi berbagai situasi dan kondisi yang dihadapi dalam proses pembelajaran.

Metode berasal dari Bahasa Yunani "Methodos" yang berarti cara atau jalan yang ditempuh. Sehubungan dengan upaya ilmiah,maka metode menyangkut masalah cara kerja untuk dapat memahami objek yang menjadi sasaran ilmu yang bersangkutan. Fungsi metode berarti sebagai alat untuk mencapai tujuan.

Dalam proses pembelajaran dikenal beberapa istilah yang memiliki kemiripan makna, sehingga seringkali orang merasa bingung untuk 
membedakannya. Istilah-istilah tersebut adalah: (1) pendekatan pembelajaran, (2) strategi pembelajaran, (3) metode pembelajaran; (4) teknik pembelajaran; (5) taktik pembelajaran; dan (6) model pembelajaran. Berikut ini akan dipaparkan istilah-istilah tersebut, dengan harapan dapat memberikan kejelasaan tentang penggunaan istilah tersebut.

Pendekatan pembelajaran dapat diartikan sebagai titik tolak atau sudut pandang kita terhadap proses pembelajaran, yang merujuk pada pandangan tentang terjadinya suatu proses yang sifatnya masih sangat umum, di dalamnya mewadahi, menginsprasi, menguatkan, dan melatari metode pembelajaran dengan cakupan teoritis tertentu. Dilihat dari pendekatannya, pembelajaran terdapat dua jenis pendekatan, yaitu: (1) pendekatan pembelajaran yang berorientasi atau berpusat pada siswa (student centered approach) dan (2) pendekatan pembelajaran yang berorientasi atau berpusat pada guru (teacher centered approach).

Dari pendekatan pembelajaran yang telah ditetapkan selanjutnya diturunkan ke dalam strategi pembelajaran. Newman dan Logan (Abin Syamsuddin Makmun, 2003) mengemukakan empat unsur strategi dari setiap usaha, yaitu :

1. Mengidentifikasi dan menetapkan spesifikasi dan kualifikasi hasil (out put) dan sasaran (target) yang harus dicapai, dengan mempertimbangkan aspirasi dan selera masyarakat yang memerlukannya.

2. Mempertimbangkan dan memilih jalan pendekatan utama (basic way) yang paling efektif untuk mencapai sasaran.

3. Mempertimbangkan dan menetapkan langkahlangkah (steps) yang akan ditempuh sejak titik awal sampai dengan sasaran.

4. Mempertimbangkan dan menetapkan tolak ukur (kriteria) dan patokan ukuran (standard) untuk mengukur dan menilai taraf keberhasilan (achievement) usaha.

Selanjutnya metode pembelajaran dijabarkan ke dalam teknik dan gaya pembelajaran. Dengan demikian, teknik pembelajaran dapat diatikan sebagai cara yang dilakukan seseorang dalam mengimplementasikan suatu metode secara spesifik. Misalkan, penggunaan metode ceramah pada kelas dengan jumlah siswa yang relatif banyak membutuhkan teknik tersendiri, yang tentunya secara teknis akan berbeda dengan penggunaan metode ceramah pada kelas yang jumlah siswanya terbatas. Demikian pula, dengan penggunaan metode diskusi, perlu digunakan teknik yang berbeda pada kelas yang siswanya tergolong aktif dengan kelas yang siswanya tergolong pasif. Dalam hal ini, guru pun dapat berganti-ganti teknik meskipun dalam koridor metode yang sama.

Sementara taktik pembelajaran merupakan gaya seseorang dalam melaksanakan metode atau teknik pembelajaran tertentu yang sifatnya individual. Misalkan, terdapat dua orang sama-sama menggunakan metode ceramah, tetapi mungkin akan sangat berbeda dalam taktik yang digunakannya. Dalam penyajiannya, yang satu cenderung banyak diselingi dengan humor karena memang dia memiliki sense of humor yang tinggi, sementara yang satunya lagi kurang memiliki sense of humor, tetapi lebih banyak menggunakan alat bantu elektronik karena dia memang sangat menguasai bidang itu. Dalam gaya pembelajaran akan tampak keunikan atau kekhasan dari masingmasing guru, sesuai dengan kemampuan, pengalaman dan tipe kepribadian dari guru yang bersangkutan. Dalam taktik ini, pembelajaran akan menjadi sebuah ilmu sekaligus juga seni.

Untuk mencapai hasil yang diharapkan dalam proses pembelajaran ada beberapa metode dalam pengajaran bahasa Asing yang bisa digunakan dalam mendukung proses belajar mengajar, diantaranya adalah : Metode gramatika-tarjemah, Metode langsung, Metode Membaca, Metode Audiolingual, Metode Komunikatif, Metode Eklektik.

\section{METODE PENELITIAN}

\subsection{Pendekatan Penelitian}

Penelitian ini dilakukan dengan menggunakan pendekatan kualitatif

\subsection{Subjek Penelitian}

Subjek penelitian ini adalah dosen pengampu mata kuliah kemahiran berbahasa yang berasal dari empat program studi yang ada di Fakultas Sastra Universitas Al Azhar Indonesia yang dijadikan subjek dalam penelitian sebanyak 20 orang. 


\subsection{Teknik Pengumpulan Data}

Dalam penelitian ini, peneliti menggunakan dua teknik pengumpulan data, yaitu wawancara dan observasi

\subsection{Alat Bantu pengumpulan Data}

Dalam mengumpulkan data-data penulis membutuhkan alat Bantu (instrumen penelitian). Dalam penelitian ini peneliti menggunakan 3 alat bantu, yaitu: Pedoman wawancara, Pedoman Observasi dan Angket yang ditulis berdasarkan urutan kebutuhan peneliti untuk mendapatkan keotentikan jawaban yang disampaikan oleh subjek.

\subsection{Teknik Analisis Data}

Berdasarkan data yang diperoleh, maka pengolahan data selanjutnya diolah dan dianalisis dengan menggunakan analisis:

1. Analisis Statistik Deskriptif : data angket yang diisi oleh responden dianalisis dengan statistik deskriptif guna melihat kecenderungan data tentang persepsi responden.

2. Analisis Kualitatif: data hasil analisis statistik deskriptif selanjutnya dijelaskan secara kualitatif melalui hasil deskripsi observasi dan wawancara dengan responden.

\section{PEMBAHASAN}

\subsection{Gambaran lokasi dan identitas responden penelitian.}

Penelitian Kompetensi Metodologis Dosen Fakultas Sastra Universitas Al Azhar Indonesia Dalam Pengajaran Kemahiran Berbahasa Asing dilakukan lingkungan Fakultas Sastra Universitas Al Azhar Indonesia, dari empat program studi yang ada: Sastra Arab, Sastra China, Sastra Inggris dan Sastra Jepang. Dari masing-masing dosen program studi data dikumpulkan yang berjumlah sebanyak 20 orang dosen. Ke dua puluh dosen ini berasal dari:

1. Dosen Sastra Arab sebanyak 5 orang,

2. Dosen Sastra China sebanyak 5 orang,

3. Dosen Sastra Inggris sebanyak 5orang, dan

4. Dosen Sastra Jepang sebanyak 5 orang.

Selengkapnya gambaran responden penelitian adalah sebagaimana data dalam tabel 1 .

Berdasarkan tabel 1 diketahui bahwa dari setiap program studi yang ada di Fakultas Sasta UAI, dari empat program studi yang ada diambil masingmasing lima orang dosen yang mengajar mata kuliah kemahiran berbahasa, sehingga jumlah totalnya 20 orang. Pertanyaan berikutnya adalah bagaimana sebaran responden berdasarkan jenis kelamin pengajar mata kuliah kemahiran berbahasa di Fakultas Sastra UAI, profil dosen berdasarkan umur dapat dilihat dalam tabel 2.

Berdasarkan tabel 2 didapati data bahwa jumlah dosen yang dijadikan responden berdasarkan umur didapati bahwa, sebanyak 12 orang atau sekitar $60 \%$ dari dosen berumur antara 20-40 tahun, penempatan usia antara 20-40 tahun ini sengaja penulis kelompokan dengan asumsi bahwa usia ini adalah usia yang sangat produktif dalam pembelajaran bahasa asing di Fakultas Sastra UAI, di usia yang relatif muda ini diharapkan lahir terobosan dalam memaksimalkan kemampuan mereka dalam pengembangan metodologi pengajaran dan kenyataan ini merupakan "kekayaan" yang dimiliki oleh Fakultas Sastra UAI. Sementara untuk responden yang berumur antara 41-50 tahun didapati hanya 1 orang atau sekitar 5\%. Sementara responden yang berumur antara 51-60 berjumlah 7 orang atau sekitar 35\%.

Tabel 1. Jumlah Dosen yang dijadikan responden

\begin{tabular}{lcc}
\hline \multicolumn{1}{c}{ Prodi Asal } & Frekuensi & Persentase (\%) \\
\hline Dosen Sastra Arab & 5 & 25.0 \\
Dosen Sastra China & 5 & 25.0 \\
Dosen Sastra Inggris & 5 & 25.0 \\
Dosen Sastra Jepang & 5 & 25.0 \\
Total & 20 & 100.0 \\
\hline
\end{tabular}

Tabel 2. Sebaran responden berdasarkan umur

\begin{tabular}{lcc}
\hline Pengelompokan Umur & Frekuensi & Persentase (\%) \\
\hline Umur 20-40 & 12 & 60.0 \\
Umur 41-50 & 1 & 5.0 \\
Umur 51-60 & 7 & 35.0 \\
Umur 61-70 & - & - \\
Total & 20 & 100.0 \\
\hline
\end{tabular}

Dari data ini dapat kita tarik simpulan bahwa terdapat keseimbangan antara jumlah dosen senior dan dosen muda pengampu mata kuliah kemahiran berbahasa di Fakultas Sastra UAI. Pernyataan ini peneliti dapatkan ketika dilakukan wawancara dan observasi dilapangan, penulis juga mendapatkan kenyataan bahwa di Fakultas Sastra UAI dalam menambah keilmuan dan wawasan dosen muda dalam pengembangan dan penerapan metodologi 
pembelajaran mereka sering kali melakukan diskusi dan tukar pendapat dengan para dosen senior, kebiasaan baik ini perlu dipertahankan sebagai salah satu upaya dalam meningkatkan kemampuan dosen dalam penerapan metodologi yang ideal dalam pembelajaran bahasa asing. Pertanyaan berikutnya adalah bagaimana sebaran responden berdasarkan jenjang pendidikan terakhir dosen pengajar mata kuliah kemahiran berbahasa di Fakultas Sastra UAI, profil dosen berdasarkan jenjang pendidikan dapat dilihat dalam tabel 3.

Tabel 3. Sebaran responden berdasarkan jenjang pendidikan

\begin{tabular}{lcc}
\hline $\begin{array}{c}\text { Pengelompokan } \\
\text { Jenjang Pendidikan }\end{array}$ & Frekuensi & Persentase (\%) \\
\hline Strata Satu (S1) & 4 & 20.0 \\
Strarta Dua (S2) & 14 & 70.0 \\
Strara Tiga (S3) & 2 & 10.0 \\
Total & 20 & 100.0 \\
\hline
\end{tabular}

Berdasarkan tabel 3 didapati data bahwa jumlah dosen yang dijadikan responden berdasarkan jenjang pendidikan terakhir didapati bahwa, hanya sekitar 4 orang atau sekitar 20\% dari dosen saja yang lulusan Strata Satu (S1), itupun ketika peneliti mengadakan wawancara dan observasi dilapangan didapati kenyataan bahwa empat orang dosen bersangkutan sekarang sedang ditahap akhir penyelesaian S2 mereka. Keinginan untuk mencapai pendidikan jenjang S2 ini sejalan dengan kebijakan Universitas Al Azhar Indonesia yang menyatakan bahwa dosen UAI minimal harus S2, karena ini adalah salah satu syarat/standar yang ditetapkan oleh Kemendiknas. Sementara untuk responden Strata Dua (S2) berjumlah sebanyak 14 orang atau $70 \%$. Jumlah 14 orang, ini merupakan jumlah mayoritas. Di UAI dosen yang mengajar harus sudah S2, dan ada tuntutan dan dorongan dari universitas untuk mereka melanjutkan pendidikan mereka ke jenjang S3, hal ini sesuai dengan harapan dekan Fakultas Sastra UAI guna untuk melakukan pengelolaan dan pengajaran kemahiran berbahasa yang ideal di Fakultas Sastra UAI para dosen diharapkan memiliki keilmuan lebih dan jenjang pendidikan yang lebih tinggi dari yang sudah didapati saat ini. Sementara responden lulusan Strata Tiga (S3) hanya sebanyak 2 orang atau sekitar $10 \%$. Dari data ini dapat kita tarik simpulan sementara bahwa dilihat dari kenyataan yang ada bahwa keberadaan dosen S2 yang ada di Fakuktas Sastra UAI sudah cukup tepat dan sudah seharusnya, sejalan dengan pertanyaan sebelumnya terkait umur responden. Mayoritas responden berumur antara 20-40 tahun, ini artinya mereka yang berusia produktif ini rata-rata saat ini sudah menamatkan pendidikan mereka di jenjang S2 dan perlu ditingkatkan lagi ke jenjang S3.

\subsection{Karakteristik Pembelajaran Bahasa Asing}

\subsubsection{Latar Belakang Dosen dalam Pengenalan dan Penguasaan Metodologi Pengajaran}

Penerapan penggunaan metodologi pengajaran bahasa asing yang tepat dalam proses pembelajaran merupakan penentu keberhasilan tercapainya proses pembelajaran bahasa dilakukan. Ketercapaian bahan ajar dilihat dari sudut pembelajar salah satunya ditentukan dari kemampuan pengajar dalam memilih dan menerapkan metodologi yang digunakan dalam proses pembelajaran. Pemilihan metodologi yang tepat bukan didasari oleh kemampuan yang dimiliki dosen pengajar, akan tetapi dilihat dari sejauh mana kecocokan materi yang akan diajarkan dengan metode yang dipilih oleh pengajar. Pada bagian ini kita akan melihat sejauh mana latar belakang pengenalan dosen yang mengajar kemahiran bahasa asing di Fakultas Sastra UAI terkait keilmuan metodologi pengajaran dan aktifitas yang dilakukan untuk memenuhi kebutuhan dosen dalam mengajarkan kemahiran bahasa asing yang ideal. Pada poin ini peneliti membuat acuan yang tertuang dalam pertanyaan yang dibagi kedalam lima bagian besar yang analisanya berdasarkan pengelompokan khusus.

Untuk melihat sejauh mana keilmuan yang dimiliki oleh dosen pengampu mata kuliah kemahiran berbahasa di Fakultas Sastra UAI mengenal dan menguasai konsep dasar metodologi pembelajaran bahasa asing dapat kita lihat di tabel 4 . Tabel yang ada mengacu kepada pertanyaan-pertanyaan yang dilontarkan oleh peneliti ketika membagikan angket, wawancara dan observasi dilapangan.

Tabel 4. Awal Pertama Responden Mengenal Metodologi Pengajaran bahasa Asing

\begin{tabular}{lcc}
\hline $\begin{array}{c}\text { Pengelompokan berdasarkan } \\
\text { Awal Mengenal Metodologi } \\
\text { Pengajaran Bahasa Asing }\end{array}$ & Frekuensi & $\begin{array}{c}\text { Persentase } \\
(\%)\end{array}$ \\
\hline $\begin{array}{l}\text { Jenjang Pendidikan Formal } \\
\text { (Sesuai Jurusan) }\end{array}$ & 2 & 10.0 \\
$\begin{array}{l}\text { Jenjang Pendidikan Formal } \\
\text { (Bagian dari Mata Kuliah) }\end{array}$ & 7 & 35.0 \\
$\begin{array}{l}\text { Kursus dan Pelatihan } \\
\text { Belajar Mandiri/Otodidak }\end{array}$ & 8 & 40.0 \\
Total & 3 & 15.0 \\
\hline
\end{tabular}


Dari tabel 4 didapatkan data bahwa hanya 2 orang atau $10 \%$ dari responden yang mengajar bahasa asing di Fakultas Sastra sesuai dengan penjurusan mereka tekuni ketika mereka belajar dibangku pendididikan formal baik S1, S2, maupun S3 yang dibuktikan dengan ijazah yang mereka dapatkan. Sementara ada sekitar 7 orang atau $35 \%$ mengenal dan memperoleh ilmu terkait metodologi pengajaran bahasa asing sebagai bagian mata kuliah yang diajarkan ataupun mata kuliah pilihan yang diambil ketika mereka kuliah dulu. Sementara ada 8 orang dan ini merupakan jumlah terbanyak $40 \%$ mendapatkan keilmuan terkait metodologi pembelajaran bahasa asing setelah mereka menamatkan pendidikan mereka di pendidikan formal di lembaga kursus dan pelatihan karena tuntutan pekerjaan yang mengharuskan mereka mendalami keilmuan terkait metodologi pengajaran bahasa asing baik itu di lembaga asing, ikatan profesi dan lain-lain. Sementara ada sebanyak 3 orang atau $15 \%$ dari responden tidak mendapatkan keilmuan terkait metodologi di bangku pendidikan, tidak juga sebagai bagian dari mata kuliah, tidak juga di lembaga kursus dan pelatihan, akan tetapi didapatkan secara otodidak/belajar mandiri karena kebutuhan pekerjaan yang ditekuni. Dari analisa berdasarkan wawancara dan observasi yang dilakukan dan sesuai dengan angket yang diberikan, untuk memenuhi kebutuhan yang harus dimiliki pengajar bahasa asing terkait metodologi pengajaran bahasa asing, berbagai usaha telah dilakukan oleh para dosen, diantaranya: dengan memperkaya keilmuan mereka dari literatur buku panduan dan rujukan terkait metodologi pengajaran bahasa, mengikuti pelatihan atau kursus yang diadakan oleh lembaga baik pemerintah maupun swasta begitu juga di kajian khusus organisasi profesi tempat responden bergabung. Satu orang dari responden tidak memberikan komentar ketika ditanyakan usaha yang dilakukan dalam menambah keilmuan responden mengenal lebih jauh metodologi yang digunakan dalam pembelajaran bahasa asing.

Untuk meningkatkan kemampuan dalam metodologi pengajaran tentunya para pendidik tidak pernah puas dengan kemampuan yang saat ini telah dimiliki, perkembangan zaman dan teknologi menuntut seseorang untuk senantiasa meningkatkan keprofesionalismeannya dalam mengajar. Untuk melihat sejauh mana kreatifitas dosen Fakultas Sastra, terutama terkait dengan usaha yang dilakukan untuk meningkatkan skil yang mereka miliki, peneliti menanyakan tentang pernahkan bapak/ibu mengikuti kursus/training/pelatihan dalam memperkuat keilmuan tentang penerapan metodologi pembelajaran bahasa asing?, beragam jawaban yang muncul merespon pertanyaan ini, sebagaimana yang tergambar dalam tabel 5 .

Tabel 5. Responden Mengikuti Pelatihan dan Kursus Metodologi Pembelajaran

\begin{tabular}{lcc}
\hline $\begin{array}{c}\text { Pengelompokan } \\
\text { Berdasarkan }\end{array}$ & & \\
$\begin{array}{c}\text { Keikutsertaan Mengikuti } \\
\text { Pelatihan dan Kursus }\end{array}$ & Frekuensi & $\begin{array}{l}\text { Persentase } \\
(\%)\end{array}$ \\
Metodologi Pembelajaran & & \\
\hline $\begin{array}{l}\text { Pernah Mengikuti Kursus/ } \\
\text { Pelatihan }\end{array}$ & 16 & 80.0 \\
Tidak Pernah Mengikuti & 3 & 15.0 \\
$\begin{array}{l}\text { Kursus/Pelatihan } \\
\text { Tidak Menjawab }\end{array}$ & 1 & 5.0 \\
Total & 20 & 100.0 \\
\hline
\end{tabular}

Dari tabel 5 didapati data bahwa 16 orang dosen atau $80 \%$ pernah mengikuti kursus dan pelatihan mengenal dan memperkaya diri dalam ilmu terkait metodologi pembelajaran bahasa asing, sementara 3 orang atau $15 \%$ tidak pernah mengikuti pelatihan yang diadakan dan 1 orang atau 5\% tidak menyatakan pendapatnya terkait keikutsertaan yang bersangkutan pernah atau tidaknya mengikuti pelatihan metodologi pengajaran bahasa asing.

Ketika ditanyakan seberapa pentingkah menurut bapak/ibu perlunya kita sebagai dosen harus menambah keilmuan kita dalam penguasaan metodologi pembelajaran bahasa asing, 20 orang responden atau $100 \%$ mengatakan bahwa sebagai seorang dosen memandang sangat penting perlunya meningkatkan kemampuan diri menguasai berbagai macam metodologi pengajaran. Dari data ini terlihat bahwa dosen pengajar kemahiran berbahasa di Fakultas Sastra UAI sudah menyadari sepenuhnya bahwa meningkatkan kemampuan dosen dalam penggunaan metodologi yang tepat merupakan satu keharusan dan harus dibarengi dengan usaha kongkrit untuk meningkatkan kemampuan tersebut. Akan tetapi penilaian ini belum relevan dengan program kerja nyata dari prodi dan fakultas untuk memberikan pelatihan kepada para dosen pengampu mata kuliah kemahiran berbahasa sebagai usaha meningkatkan kemampuan dosen dalam menguasai keilmuan tentang metodologi pengajaran bahasa asing. Masih beragam jawaban dari responden ketika ditanyakan apa yang dilakukan oleh prodi tempat bapak/ibu mengajar saat ini dalam meningkatkan pengetahuan terkait metodologi pembelajaran yang digunakan 
dalam pembelajaran bahasa asing? 7 orang dosen atau $35 \%$ menyatakan bahwa fakultas dan program studi pernah mengikutsertakan para dosen dalam pelatihan-pelatihan yang diadakan terkait metodologi pembelajaran bahasa asing dan 7 orang atau $35 \%$ juga mengatakan untuk meningkatkan kemampuan mereka dalam dari prodi lebih banyak melakukan diskusi-diskusi lepas dan sharing ilmu sesama dosen terkait problematika yang dihadapi ketika mengajarkan mata kuliah kemahiran dan mendiskusikannya untuk mencari solusi yang tepat ketika berhadapan dengan kondisi tertentu dalam penyampaian bahan ajar dikelas. Akan tetapi cukup mencengangkan juga ketika ada 6 orang atau 30\% dari responden menjawab bahwa prodi tidak pernah melakukan apa-apa terkait pelatihan ataupun diskusi yang dilakukan ditingkat prodi terkait peningkatan kemampuan dosen pengajar mata kuliah kemahiran dalam mengajar bahasa asing

\subsubsection{Penerapan Metodologi Pengajaran dalam Pembelajaran Bahasa Asing}

Untuk melihat sejauh mana dosen Fakultas Sastra UAI menerapkan metodologi yang ideal dalam pembelajaran bahasa asing, marilah kita lihat hasil dan analisa yang penulis lakukan ketika peneliti melakukan wawancara, observasi dan pembagian angket untuk memperkuat pendapat responden terkait penerapan metodologi pengajaran bahasa asing. Untuk lebih memudahkan marilah kita lihat secara lebih detil di tabel 6 .

Tabel 6. Sebaran jawaban responden terkait penerapan dosen dalam metodologi yang ideal dalam pengajaran bahasa asing di Fakultas Sastra UAI.

\begin{tabular}{|c|c|c|c|c|c|c|}
\hline \multirow[b]{2}{*}{ No } & \multirow[b]{2}{*}{ Pernyataan } & \multicolumn{5}{|c|}{ Alternatif Jawaban (\%) } \\
\hline & & $\begin{array}{l}\text { Sangat } \\
\text { Setuju }\end{array}$ & Setuju & $\begin{array}{c}\text { Tidak } \\
\text { Berpendapat } \\
\end{array}$ & $\begin{array}{l}\text { Tidak } \\
\text { Setuju }\end{array}$ & $\begin{array}{c}\text { Sangat } \\
\text { T.S }\end{array}$ \\
\hline 1. & $\begin{array}{l}\text { Saya mengajar kemahiran berbahasa di Fakultas } \\
\text { Sastra UAI dengan metodologi pengajaran yang } \\
\text { sudah ideal }\end{array}$ & 5.0 & 75.0 & 5.0 & 15.0 & - \\
\hline 2. & $\begin{array}{l}\text { Dengan kemampuan yang saya miliki saat ini, } \\
\text { saya masih merasa perlu untuk meningkatkan } \\
\text { kemampuan saya dalam penguasaan dan } \\
\text { penerapan metodologi pengajaran bahasa asing }\end{array}$ & 65.0 & 35.0 & - & - & - \\
\hline 3. & $\begin{array}{l}\text { Bagi saya penguasaan metodologi bahasa asing } \\
\text { tidak perlu didapatkan dengan pendidikan khusus, } \\
\text { akan tetapi dapat dipelajari secara mandiri }\end{array}$ & & 20.0 & 10.0 & 55.0 & 15.0 \\
\hline 4. & $\begin{array}{l}\text { Saya dalam mengajar kemahiran bahasa asing } \\
\text { sangat terpengaruh oleh cara/metode yang } \\
\text { digunakan oleh guru dan dosen saya ketika dulu } \\
\text { saya masih sekolah dan kuliah }\end{array}$ & 15.0 & 40.0 & 5.0 & 35.0 & 5.0 \\
\hline 5. & $\begin{array}{l}\text { Dalam menggunakan metode yang tepat dalam } \\
\text { pembelajaran bahasa asing saya lebih memilih } \\
\text { metode yang benar-benar saya kuasai dan } \\
\text { kemudian saya sesuaikan dengan bahan ajar yang } \\
\text { saya harus sampaikan }\end{array}$ & 25.0 & 50.0 & 5.0 & 20.0 & - \\
\hline 6. & $\begin{array}{l}\text { Kemahiran berbahasa sebagai mata kuliah yang } \\
\text { saya ajar tidak perlu didukung oleh alat bantu } \\
\text { (media) yang cocok, karena sudah cukup dengan } \\
\text { memaksimalkan Lab Bahasa yang ada }\end{array}$ & - & 15.0 & - & 60.0 & 25.0 \\
\hline 7. & $\begin{array}{l}\text { Saya mengelola kelas dengan memanfaatkan } \\
\text { seluruh komponen yang ada dalam pembelajaran } \\
\text { kemahiran bahasa, seperti mahasiswa, uku ajar, } \\
\text { alat peraga dll }\end{array}$ & 15.0 & 85.0 & - & - & - \\
\hline
\end{tabular}


Berdasarkan deskripsi data sebagaimana tampak dalam tabel 6, di pernyataan No. 1 dapat ditarik suatu simpulan bahwa penggunaan metodelogi yang tepat yang dilaksanakan oleh dosen pengampu mata kuliah bahasa asing di Fakultas Sastra UAI sudah dipandang ideal oleh dosen yang bersangkutan, sekitar $80 \%$ dari total responden menyadari sepenuhnya dengan keahlian dan pengalaman yang responden miliki meyakini bahwa ketercapaian bahan ajar yang diajarkan kepada anak didik sudah maksimal dan sudah sesuai dengan konsep metodologi pembelajaran bahasa asing yang sebenarnya, sementara sekitar $15 \%$ menyadari bahwa kemampuan responden mengajar bahasa asing di Fakultas Sastra belumlah ideal sesuai dengan standar yang diinginkan, boleh jadi penilaian ini muncul karena memang responden merupakan dosen baru dilingkungan Fakultas.

Pada poin No. 2, ketika dinyatakan bahwa dengan kemampuan yang responden miliki saat ini, responden masih merasa perlu untuk meningkatkan kemampuannya dalam penguasaan dan penerapan metodologi pengajaran bahasa asing, didapati $100 \%$ responden menyatakan bahwasanya kemampuan yang mereka miliki terkait penguasaan metodologi pengajaran bahasa asing belum maksimal dan masih perlu ditingkatkan. Pernyataan ini merupakan jawaban dari kebutuhan pendidik dalam mengahadapi tantangan zaman untuk melahirkan anak didik yang siap terjun ke dunia kerja dengan kemahiran berbahasa yang dibutuhkan oleh pasar atau dunia kerja.

Ketika dinyatakan pada poin No. 3, bagi responden penguasaan metodologi bahasa asing tidak perlu didapatkan dengan pendidikan khusus, akan tetapi dapat dipelajari secara mandiri. Pernyataan ini dijawab dengan jawaban yang beragam oleh responden, $70 \%$ menyatakan tidak setuju dengan pernyataan ini karena memang ilmu tentang metodologi tidak dengan mudah didapatkan begitu saja, akan tetapi harus dengan pendidikan khusus, keilmuan ini bisa didapatkan dengan pendidikan yang terstruktur seperti kuliah di fakultas pendidikan dan keguruan ataupun pendidikan khusus profesi sebagaimana yang dilaksanakan oleh calon guru yang dikenal dengan AKTA IV sebagai prasyarat untuk seseorang boleh untuk mengajar di lembaga resmi, ataupun ikut di pelatihan khusus yang diadakan baik oleh pemerintah maupuan lembaga pendidikan swasta lainnya. Sementara ada sekitar $20 \%$ menyatakan setuju dengan pernyataan penguasaan metodologi bahasa asing tidak perlu didapatkan dengan pendidikan khusus, akan tetapi dapat dipelajari secara mandiri.

Ketika dinyatakan pada poin No. 4 terkait responden dalam mengajar kemahiran bahasa asing di sangat terpengaruh oleh cara/metode yang digunakan oleh guru dan dosen responden ketika dulu saya masih sekolah dan kuliah. Sebuah kelaziman memang, akan tetapi jawaban responden cukup beragam: $55 \%$ dari responden setuju dengan pernyataan responden dalam mengajar kemahiran berbahasa asing sangat terpengaruh oleh cara/metode yang digunakan oleh guru dan dosen responden ketika dulu saya masih sekolah dan kuliah. Bisa jadi besarnya jumlah responden yang setuju dengan pernyataan ini karena kebanyakan dari responden bukan berasal dari fakultas pendidikan, sebanyak 16 orang responden atau $80 \%$ berasal dari jurusan budaya dan sastra serta jurusan linguistik, sehingga cara mengajar guru/dosen nya dulu sangat mempengaruhi yang bersangkutan dalam mengajar kemahiran berbahasa di Fakultas Sastra UAI. Tidak selamanya pendapat ini salah, karena pengalaman dari guru dan dosen yang mengajar jauh lebih otentik dibandingkan dengan teori yang didapatkan, akan tetapi kalau pengalaman yang didapatkan ini didasari dengan kerangka teori yang tepat dari pendidikan yang terstruktur dan dipadu dengan keahlian yang dimiliki diri sendiri tentunya akan mendatangkan dampak yang jauh lebih baik terkait penerapan metodologi pengajaran bahasa asing yang digunakan. Sementara 40\% responden menyatakan tidak setuju ketika dinyatakan bahwa responden dalam mengajar kemahiran bahasa asing sangat terpengaruh oleh cara/metode yang digunakan oleh guru dan dosen responden ketika dulu saya masih sekolah dan kuliah, pernyataan seperti ini muncul kemungkinan dilatari oleh penguatan kemampuan responden setelah selesai kuliah mengikuti pelatihan dan kursus khusus terkait penguasaan metodologi pembelajaran yang digunakan dalam mengajarkan bahasa asing di Fakultas Sastra UAI.

Ketika dinyatakan di poin No. 5, bahwa dalam menggunakan metode yang tepat dalam pembelajaran bahasa asing responden lebih memilih metode yang benar-benar responden kuasai dan kemudian responden sesuaikan dengan bahan ajar yang responden harus sampaikan, didapati kenyataan bahwa $75 \%$ dari responden menyatakan setuju dengan pernyataan tersebut. Muncul pertanyaan, apakah responden setuju 
dengan pernyataan ini benar murni karena pemahaman responden bahwa pemilihan metodologi yang tepat dalam pembelajaran bahasa dilihat dari sudut pengajarnya bukan dari materi yang akan diajarkan kepada anak didik ataukah karena keterbatasan keilmuan yang dimiliki. Ketika merujuk teori pemilihan metodologi yang tepat dalam pembelajaran bahasa asing, sebagai mana yang dikatakan oleh (Fuad Effendy; 46) dinyatakan bahwa pemilihan metodologi yang tepat dalam proses pembelajaran bukan didasarkan kepada kemampuan penguasaan dosen kepada metodologi tertentu,akan tetapi dilihat dari sisi bahan ajar yang akan disampaikan kepada anak didik, bisa jadi untuk satu bahan ajar tertentu pendidik dituntut menggunakan metodologi pembelajaran lebih dari satu atau gabungan dari beberapa metodologi yang tepat. Dengan bahasa lain dikatakan bahwa pemilihan metodologi dalam pembelajaran bukan dilihat dari sisi pengajarnya, akan tetapi disesuaikan dengan kebutuhan bahan ajar itu sendiri.

Salah satu faktor penting yang harus diperhatikan oleh pendidik dalam pembelajaran bahasa asing adalah pemanfaatan media pengajaran, kemampuan dosen melakukan innovasi dengan alat batu yang beragam bisa mendatangkan motivasi tersendiri kepada anak didik dalam proses pembelajaran yang dilaksanakan,. Peneliti memasukan unsur media dalam penelitian ini karena terkait dengan sejauh mana dosen Fakultas Sastra UAI melihat peran penting penggunaan alat bantu dalam proses pembelajaran bahasa asing, untuk melihat jawaban responden dinyatakan dalam poin No. 6 bahwa kemahiran berbahasa sebagai mata kuliah yang responden ajar tidak perlu didukung oleh alat bantu (media) yang cocok, karena sudah cukup dengan memaksimalkan Lab Bahasa yang ada. Sebanyak $85 \%$ dari responden menyatakan tidak setuju dengan pernyataan yang menyatakan bahwa kemahiran berbahasa sebagai mata kuliah yang responden ajar tidak perlu didukung oleh alat bantu (media) yang cocok, karena sudah cukup dengan memaksimalkan Lab Bahasa yang ada. Hal ini disebabkan karena memang di Fakultas Sastra, Universitas Al Azhar Indonesia disediakan alat bantu dalam proses pembelajaran bahasa asing tidak hanya laboratorium bahasa tapi berbagai fasilitas pendukung disediakan seperti in focus, laptop, dan fasilitas penunjang lainnya, dan para dosenpun dipacu untuk memaksimalkan penggunaan alat bantu terbaru dalam pengajaran bahasa asing. Sementara hanya $15 \%$ dari responden yang setuju dengan pernyataan kemahiran berbahasa sebagai mata kuliah yang responden ajar tidak perlu didukung oleh alat bantu (media) yang cocok, karena sudah cukup dengan memaksimalkan Lab Bahasa yang ada, hal ini mungkin disebabkan karena faktor penguasaan media yang kurang dimiliki oleh responden. Setujunya responden dengan pernyataan perlu nya pemanfaatan media dalam proses pembelajaran sejalan dengan analisa poin akhir poin No. 7 yang ada dia angket penelitian yang menyatakan bahwa responden mengelola kelas dengan memanfaatkan seluruh komponen yang ada dalam pembelajaran kemahiran bahasa, seperti mahasiswa, buku ajar, alat peraga dll. Pernyataan ini senada dengan pernyataan sebelumnya tentang penting nya alat bantu dalam proses pembelajaran, dari pernyataan ini didapati data bahwa $100 \%$ dari responden menyatakan setuju dengan responden mengelola kelas dengan memanfaatkan seluruh komponen yang ada dalam pembelajaran kemahiran bahasa, seperti mahasiswa, buku ajar, alat peraga dan hal lain terkait alat bantu dalam proses pembelajaran.

\subsubsection{Teknik Evaluasi Ketercapaian Bahan Ajar Sebagai Unsur Penting Penerapan Metodologi Pembelajaran Bahasa Asing}

Dari hasil wawancara, observasi dan analisa angket ini peneliti mencoba mengelompokan jawaban responden kedalam 5 pengelompokan teknik evaluasi sebagai berikut:

1. Evaluasi Harian, berbagai macam aktifitas dan kegiatan dilakukan oleh para responden untuk melihat ketercapaian materi yang diajarkan dalam satu pokok bahasan tertentu, mulai dari memberi tugas harian, tugas kelompok, mencatat perkembangan anak didik dibuku pendamping sampai dengan memantau tingkat pemahaman anak didik dengan memberikan pertanyaan secara spontan diakhir pertemuan.

2. Evaluasi mingguan, diantara aktifitas yang dilakukan oleh dosen Fakultas Sastra UAI dalam mengevaluasi tingkat ketercapaian materi lewat evaluasi mingguan adalah: memberi tugas mingguan, PR, tes yang dikerjakan dirumah dan observasi dll.

3. Evaluasi bulanan, berbagai macam aktifitas dilakukan oleh responden seperti: memberi tes dipertemuan awal setiap bulan, membuat tugas kelompok yang dikumpulkan setiap awal bulan, evaluasi lisan dikelas secara spontan dan lainlain sesuai dengan kebutuhan evaluasi bulanan dilakukan

4. Adapun untuk Ujian Tengah Semester dan Akhir Semester, secara umum responden menjawab bahwa bentuk evaluasi yang 
dilakukan di UTS dan UAS disesuaikan dengan karakteristik mata kuliah yang diajarkan, kalau yang diajarkan kemahiran mendengar ujian dilaksanakan di lab bahasa dengan menggunakan bahasa ajar mendengar, kalau untuk mata kuliah percakapan ujian dilaksanakan secara lisan dari bahan yang sudah diajarkan, kalau untuk mata kuliah kemahiran membaca ujian dilaksanakan dengan menggunakan bahan yang diambilkan dari buku paket pengajaran dan sumber lainnya, sementara untuk kemahiran menulis responden menguji dalam bentuk tulisan yang digabung dengan penguasaan anak didik terkait penerapan tata bahasa dalam kontens penulisan.

\section{KESIMPULAN}

1. Dosen Fakutas Sastra UAI yang mengajar mata kuliah kemahiran berbahasa berumur antara 2040 tahun, sebanyak 12 orang atau $60 \%$, usia antara 20-40 tahun diasumsikan bahwa ini adalah usia yang sangat produktif dalam pembelajaran bahasa asing di Fakultas Sastra UAI, di usia yang relatif muda ini diharapkan lahir terobosan-terobosan dalam memaksimalkan kemampuan mereka dalam pengembangan metodologi pengajaran dan kenyataan ini merupakan "kekayaan" yang dimiliki oleh Fakultas Sastra UAI

2. Mayoritas dosen yang mengajar kemahiran berbahasa di Fakultas Sastra UAI adalah dosen yang sudah memenuhi kualifikasi akademik yang memadai dengan jumlah.

3. Terdapat keragaman antara dosen yang mengajar kemahiran berbahasa dilingkungan Fakultas Sastra UAI dilihat dari sudut latar belakang pendidikannya, ada yang berasal dari pendidikan kejuruan dengan metodologi pembelajaran merupakan jurusan yang ditekuni.

4. Didapatkan data bahwa masih banyak dosen yang mengajar kemahiran berbahasa asing Fakultas Sastra UAI mengatakan bahwa dalam mengajar kemahiran bahasa asing mereka masih terpengaruh oleh cara/metode yang digunakan oleh guru dan dosen mereka ketika dulu saya masih sekolah dan kuliah.

5. Teknik evaluasi ketercapaian bahan ajar sebagai unsur penting penerapan metodologi pembelajaran bahasa asing di Fakultas Sastra UAI sudah sesuai dengan tuntutan yang ideal.

\section{DAFTAR PUSTAKA}

\section{Buku Referensi}

[1] Prof. Dr. Aziz Fahrurrazi, MA, Erta Mahyudin, M. Pd, Pembelajaran Bahasa Arab, Direktorat Jendral Pendidikan Islam, DEPAG RI, 2009

[2] Ahmad Fuad Effendy, Metodologi Pengajaran Bahasa Arab, 2005, Penerbit Misykat Malang.

[3] Rahma Boedi dkk, 2004, Perencanaan Pembelajaran, Lembaga Akta Mengajar, UNJ.

[4] Al-Khuliy, Muhammad Ali. 2003. Model Pembelajaran Bahasa Arab. Terjemahan Asālību Tadrīsi Al-Lughah Al-`Arabiyyah oleh Yayan Nurbayan et.al. Bandung: Pusat Studi Islam dan Bahasa Arab Universitas Pendidikan Indonesia.

[5] Arsyad, Azhar. 2003. Bahasa Arab dan Metode Pengajarannya: Bebarapa Pokok Pikiran. Yogyakarta: Pustaka Pelajar.

[6] DePorter, Bobi, Mark Reardon, dan Sarah SingerNourie. 2000. Quantum Teaching: Mempraktikkan Quantum Learning di Ruang-ruang Kelas. Bandung: Kaifa.

[7] Purwanto, Ngalim. 1994. Psikologi Pendidikan. Bandung: Remaja Rosdakarya.

[8] Mustaqim Abdul Wahab, Psikologi Pendidikan. Jakarta: Rineka Cipta, 1991

[9] Sahertian, Piet dan Ida Sahertian. Superfisi Pendidikan dalam Rangka Program Inservice Education, Jakarta: Rineka Cipta, 1990

[10] Makmun Abin Syamsududin, Psikologi Pendidikan, Bandung, Remaja Rosdakarya, 1990

[11] Ruslan. A. Tabrani, Astang Kusnidar dan Zainal Arifin, Pendekatan dalam Proses Mengajar, Bandung: Remaja Karya, 1989

[12] Akhmad Sudrajat, Pengertian Pendekatan, Strategi, Metode, Teknik, Taktik, dan Model Pembelajaran

[13] Borang Sastra Arab, Sastra China, Sastra Inggris, Sastra Jepang, Pengajuan Akreditasi Jurusan yang ada di Fakultas Sastra UAI tahun 2010.

[14] Portfolio Fakultas Sastra UAI, Pengajuan Akreditasi Fakultas Sastra UAI tahun 2011.

\section{Website:}

[1] http://akhmadsudrajat.wordpress.com/daftar-isimakalah-pendidikan/

[2] http://akhmadsudrajat.wordpress.com/2009/05/12/k urikulum-berdasarkan-filsafat-behaviorisme/

[3] http://www.psb-psma.org/content/blog/pengertianpendekatan-strategi-metode-teknik-taktik-danmodel-pembelajaran

[4] achsan.staff.gunadarma.ac.id/ownloads/files/4487/ bab 3

[5] Methodologies in Foreign Language Teaching: A Brief Historical Overview. http://www.linguatics. com/methods.htm. Diunduh November 2010. 